\title{
Investigation on the morphological traits of different varieties Bora-Rice (Oryza sativa L.) cultivated in Bongaigaon District of Assam, India
}

\author{
Ranu Roy \\ Department of Botany, Birjhora Mahavidyalaya, Bongaigaon 783380, Assam, India \\ E-mail: ranuroybng@gmail.com
}

[Received 18.12.2019; Revised 11.06.2020; Accepted 15.06.2020; Published 30.06.2020]

\begin{abstract}
Along with the worldwide population explosion the demand for food-grains is increasing steadily and forcing farmers to opt for modern cultivation methods and crops of high yielding varieties, leaving aside the traditional methods and indigenous crop varieties. This has led to the extinction of some important Rice land-races from different localities. But, somehow, the farmers of Bongaigaon district of Assam are yet to given up their traditional rice cultivars from their fields. Major Rice varieties like $A b u$, Sali and Boro are cultivated in Assam. The farmers of Bongaigaon district prefer to cultivate different varieties of Bora-rice which are commonly referred as 'bonni' Rice. Present investigation in the Bongaigaon district during 2014 - 2016 recognized eight Borarice cultivars, namely Nalbonni, Buribonni, Sababonni, Sikarabonni, Anarashibonni, Bhogbonni, Kritirajbonni and Pakhatibonni. All these cultivars produce glutinous rice. The study also recognized the morphological differences among these cultivers in some important traits like grains per panicle, shape, size, weight and volume of paddy and rice grains. It was found that though all the eight cultivars of Bora-rice showed some unique characteristics, which might be utilized for their identification at cultivar level.
\end{abstract}

Key words: Bora-rice, Grain character, Bongaigaon, Assam

\section{INTRODUCTION}

People of North-Eastern region of India, though vastly culturally diverse, depends on rice as their principal crop. The germplasm collection has also unfold the occurrence of large number of rice landraces in the region (Hore 2005; Roy 2018). The indigenous germplasm of Northeast India represents a wealth of valuable gene systems (Sharma et al. 1971). North east India, including Assam, is recognized as a Centre of Origin of rice and is endowed with exceptionally rich in rice diversity (Sarma \& Bahar 2005). Variation in ecological condition, ethnic diversity, diverse cultural practices and different quality preferences contribute to the diversity present in different types of rice, locally known as Abu, Sali, Boro, Bora, Joha, Labi etc. (Pathak 2001). Bora is a glutinous rice variety and are gaining prime attention for value-added rice farming. This class of rice is required to prepare a number of food items during any festival, religious occasions and ceremonies. It has an important role in Assamese tradition as many communities here also prepare high class rice-beer using Bora-rice (Deka et al. 2014). Occasions like Bihu is not complete without different dishes made out of Bora-rice. It is used in wide variety of jolpan (snacks) and pitha (rice cake). Soaked and ground Bora-rice is used in preparing pitha. Boiled Bora-rice grain is served as jolpan with curd or milk, jaggery or sugar. Some people use Bora-rice to make simple cooked-rice or bhaat, which is very delicious, but sticky in texture. During the Ahom reign in Assam Bora-rice grains with duck-eggs was used in constructing buildings because of its sticky nature of the mixture (https//en.m.wikipedia.org). 


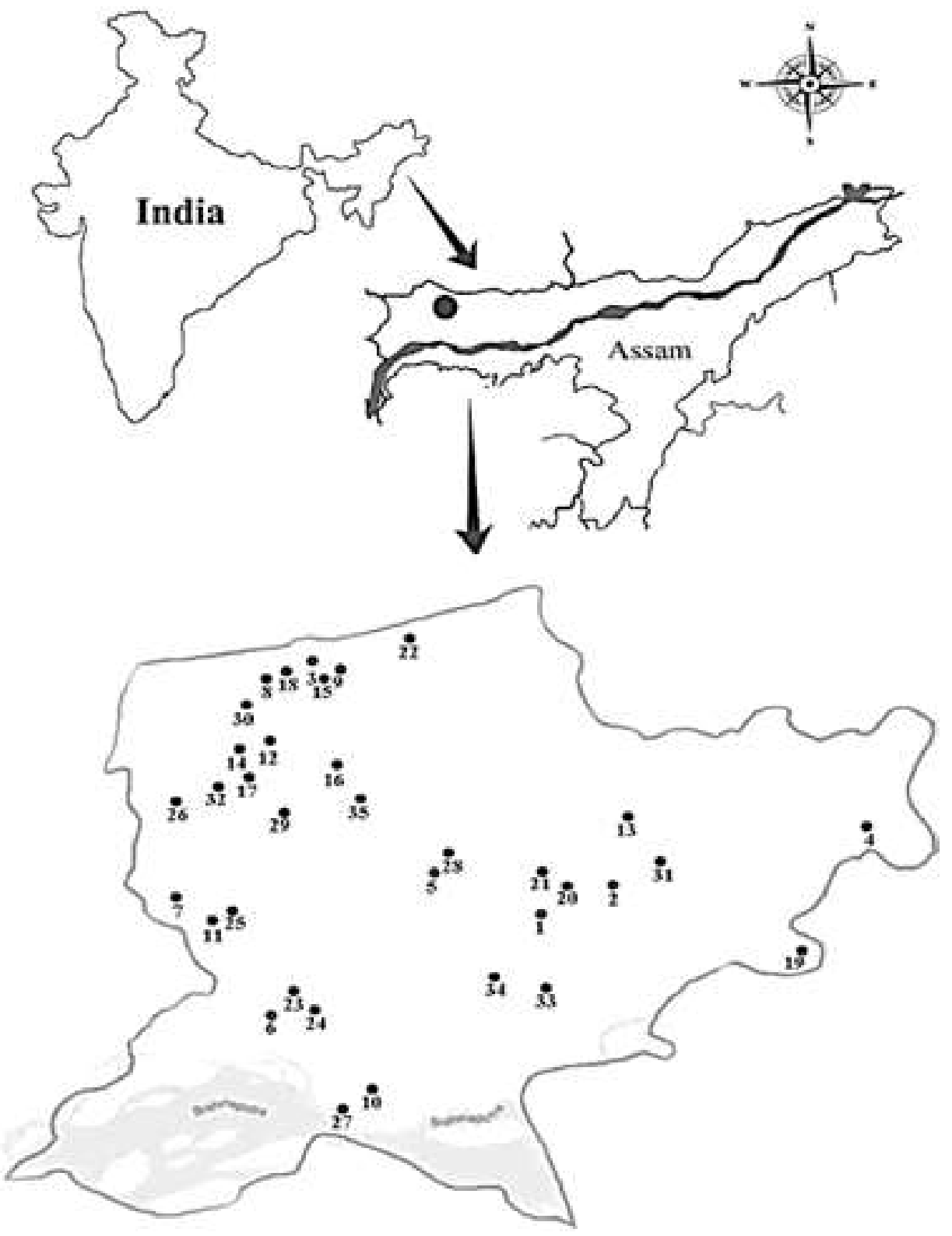

Figure 1. Location map of the Study Area [paddy fields at: S1. Deohati; S2. Srijangram; S3. Papragaon; S4. Adalaguri; S5. Khagarpur; S6. Shankarghola; S7. Nankargaon; S8. Dangtol; S9. Chitkagaon; S10. Kabaitari; S11. Kayethpar; S12. Dashimapara; S13. Sonakhuli; S14. Tengaigaon; S15. Meshpara; S16. Hatiutra; S17. Saonagaon; S18. Dolaigaon; S19. Kokila; S20. Sukani; S21. Tulungia; S22. Chaparakata; S23. Shakomura; S24. Nimagaon; S25. Talguri; S26. Bidyapur; S27. Jogighopa; S28. Nigamghola; S29. Kasharpara; S 30. Kakragaon; S31. Barghola; S32. Panchapur; S33. Lalmati; S34. Shingimari and S35. Kahidoba] 
Bongaigaon $\left(26^{\circ} 282 \mathrm{~N}\right.$ to $26^{\circ} 542 \mathrm{~N}$ and $89^{\circ} \mathrm{E}$ to $\left.89^{\circ} 962 \mathrm{E}\right)$ is an agriculturally rich district of Assam (Figure1). Terrain of the major portion of the study area is of running plains that is traversed by two rivers, Tunia and Kujia. The climate of this tropical region is characterized by the highly humid atmosphere with abundant precipitation mainly from the south-west monsoon during the months of June to September resulting in heavy rainfall. $4632.2 \mathrm{~mm} /$ annum (BGR, IOCL 2010). Prevailing favorable climate as well as the conservative and selective attitudes of different ethnic groups helped to select and preserve good number of traditional rice-varieties in the area.

To record and understand how many different types of Bora-rice is cultivated in different localities of Bongaigaon district, and how they differ from one another morphologically; a field survey was conducted during November to January (rice harvesting periods) for two consecutive years, 2014 - 2015 and 2015 - 2016 in different localities of Bongaigaon district.

\section{MATERIALS AND METHODS}

Thirty five paddy-fields from Bongaigaon district were selected randomly and named as S1, S2, S3, ....... S35 (Figure-1). The survey was conducted for two successive years, during November to January of $2014-2015$ and 2015 - 2016. This is the harvesting period for Borarice cultivars. Along with regular field visit farmers of different localities were communicated to avail information regarding the local name and mode of use for each cultivars. Paddy and rice-grains of Bora varieties were collected from these localities for the study. The parameters and methods followed were:

- Height of the plant (in meter and centimeter)

- Length of the spike (in centimeter)

- Number of grains per spike

- Length of the awn (in centimeter)

- Weight of 1000 grains of paddy and rice grain (in grams, using electronic balance)

- Volume of 1000 grains of paddy and rice grain (In cubic centimeter, using water replacement method in measuring cylinders)

- Colour of the paddy and rice grains (using standard DULUX colour chart)

- Length and breadth of the paddy and rice grains (Using Vernier calipers)

- And finally, procured data were analyzed statistically using SPSS Ver. 6.0 program (SPSS Inc, 1994)

All the paddy and rice specimens are preserved in the Birjhora college Herbarium.

\section{RESULTS AND DISCUSSION}

During the field survey 8 different indigenous cultivars of Bora-rice were recognized that are cultivated by the farmers of this region. The overall terminology in use for these cultivars is 'bonni' which is post-fixed to each varietal name. So, names of these cultivars are: Anarashibonni, Bhogbonni, Buribonni, Kritirajbonni, Nalbonni, Pakhatibonni, Sababonni and Sikarabonni.

Table 1 shows the height of the plant, length of the spike, number of grain per spike and presence or absence of awn and their length in different varieties of Bora-rice. Their average plant-height varies considerably from one another. Tallest plants were recorded for 
Pakhatibonni $(136.32 \pm 10.02 \mathrm{~cm})$ and that was followed by Anarashibonni, Sahabonni, Bhogbonni and Kritirajbonni. Shortest plants were recorded for Buribonni and Sikarabonni (102.51 \pm 8.56 and $102.51 \pm 12.51 \mathrm{~cm})$ (Figure 2).

Table 1. Height of the plant, length of the spike, number of grain per spike, length of the awn present in different cultivars of Bora-rice cultivated in Bongaigaon district (2014 to 2016)

\begin{tabular}{|l|c|c|l|l|}
\hline \multicolumn{1}{|c|}{ Cultivar } & $\begin{array}{c}\text { Plant Height } \\
(\mathbf{c m})\end{array}$ & $\begin{array}{c}\text { Spike length } \\
\mathbf{( c m})\end{array}$ & Grains/ spike & Awn length (cm) \\
\hline Nalbonni & $106.58 \pm 13.22$ & $20.38 \pm 6.12$ & $67.07 \pm 21.05$ & Absent \\
\hline Buribonni & $102.51 \pm 8.56$ & $19.55 \pm 6.38$ & $67.94 \pm 19.27$ & Absent \\
\hline Sahabonni & $114.61 \pm 8.26$ & $21.32 \pm 7.92$ & $73.00 \pm 21.26$ & 0.2 \\
\hline Sikarabonni & $102.51 \pm 12.52$ & $19.88 \pm 6.18$ & $70.94 \pm 19.33$ & Rarely present $(0.2)$ \\
\hline Anarashibonni & $121.52 \pm 10.66$ & $23.41 \pm 7.36$ & $105.61 \pm 21.92$ & Rarely present $(0.2)$ \\
\hline Bhogbonni & $112.31 \pm 9.14$ & $21.05 \pm 6.61$ & $102.46 \pm 23.06$ & 0.5 \\
\hline Kritirajbonni & $108.41 \pm 11.74$ & $19.02 \pm 6.46$ & $70.04 \pm 12.32$ & 0.2 \\
\hline Pakbatibonni & $136.32 \pm 10.02$ & $20.80 \pm 6.45$ & $70.10 \pm 24.94$ & Absent \\
\hline
\end{tabular}

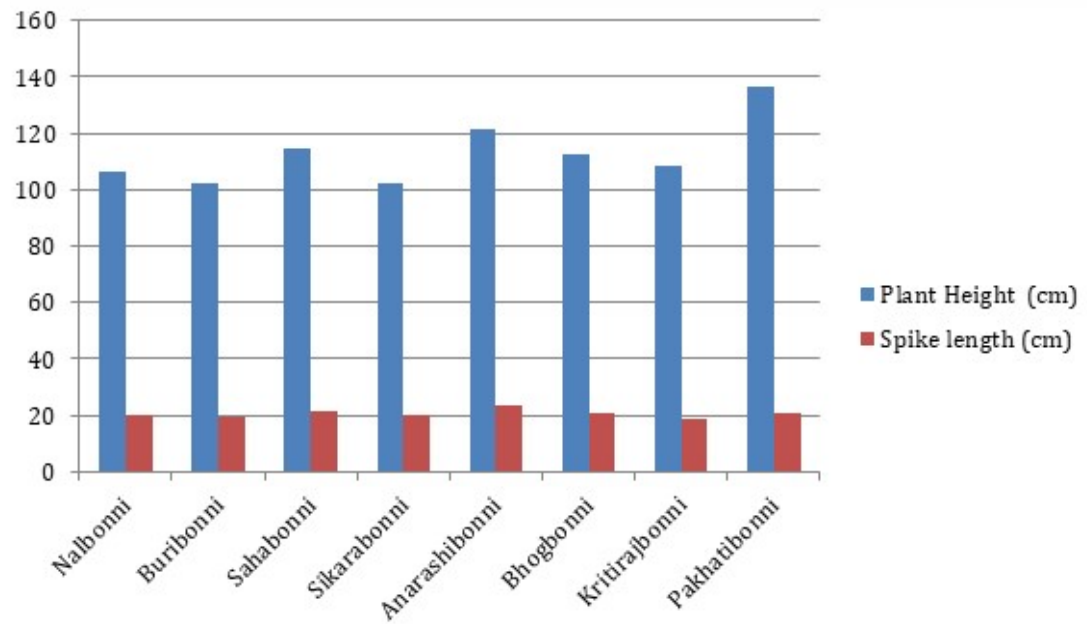

Figure 2: Height of the plant and length of the spike in different cultivars of Bora rice of Bongaigaon district.

In case of spike length of the longest spike was found in Anarashibonni $(23.41 \pm 7.36$ $\mathrm{cm})$ with highest number of grains $(105.61 \pm 21.92)$ and that was followed by Sahabonni, Bhogbonni, Nalbanni, Pakabtibonni, Kritirajbonni, Sikarabonni. The shortest spike was found in Buribonni $(19.55 \pm 6.38 \mathrm{~cm}$ ) with $67.94 \pm 19.27$ number of grain per spike (Figure 2 and Figure 3). Awn in all these cultivars are rudimentary or even missing and varies from $0-0.5 \mathrm{~cm}$ only. Nalbonni, Buribonni and Pakhatibonni were found without awn.

Table-3 shows weight, volume and colour of paddy and rice grains in different indigenous cultivars of Bora-rice cultivated in different localities of Bongaigaon district. Highest weight of 1000 grains of paddy was found in Nalbonni and Sikarabonni $(24.50 \mathrm{~g})$ which was followed by Bhogbonni, Anarashibonni Kritirajbonni, Pakbatibonni and Sababonni. Similarly, highest 
Table 2. Length and breadth of paddy and rice grain in different cultivars of Bora-rice cultivated in Bongaigaon district during the period of 2014 to 2016.

\begin{tabular}{|l|l|l|l|l|}
\hline \multirow{2}{*}{ Cultivar } & \multicolumn{2}{|c|}{ Paddy grains } & \multicolumn{2}{c|}{ Rice grains } \\
\cline { 2 - 5 } & Length (cm) & Breadth(cm) & $\begin{array}{c}\text { Length } \\
\text { (cm) }\end{array}$ & Breadth (cm) \\
\hline Nalbonni & $0.880 \pm 0.041$ & $0.292 \pm 0.038$ & $0.627 \pm 0.046$ & $0.263 \pm 0.046$ \\
\hline Buribonni & $0.895 \pm 0.088$ & $0.269 \pm 0.031$ & $0.612 \pm 0.055$ & $0.224 \pm 0.014$ \\
\hline Sababonni & $0.822 \pm 0.054$ & $0.276 \pm 0.031$ & $0.587 \pm 0.035$ & $0.250 \pm 0.026$ \\
\hline Sikarabonni & $0.735 \pm 0.039$ & $0.287 \pm 0.032$ & $0.531 \pm 0.016$ & $0.288 \pm 0.032$ \\
\hline Anarashibonni & $0.907 \pm 0.029$ & $0.311 \pm 0.008$ & $0.640 \pm 0.055$ & $0.290 \pm 0.008$ \\
\hline Bhogbonni & $0.915 \pm 0.038$ & $0.363 \pm 0.025$ & $0.693 \pm 0.035$ & $0.334 \pm 0.014$ \\
\hline Kritirajbonni & $0.782 \pm 0.054$ & $0.265 \pm 0.031$ & $0.563 \pm 0.045$ & $0.247 \pm 0.026$ \\
\hline Pakbatibonni & $0.870 \pm 0.026$ & $0.265 \pm 0.077$ & $0.555 \pm 0.044$ & $0.237 \pm 0.023$ \\
\hline
\end{tabular}

\section{Grains/spike}

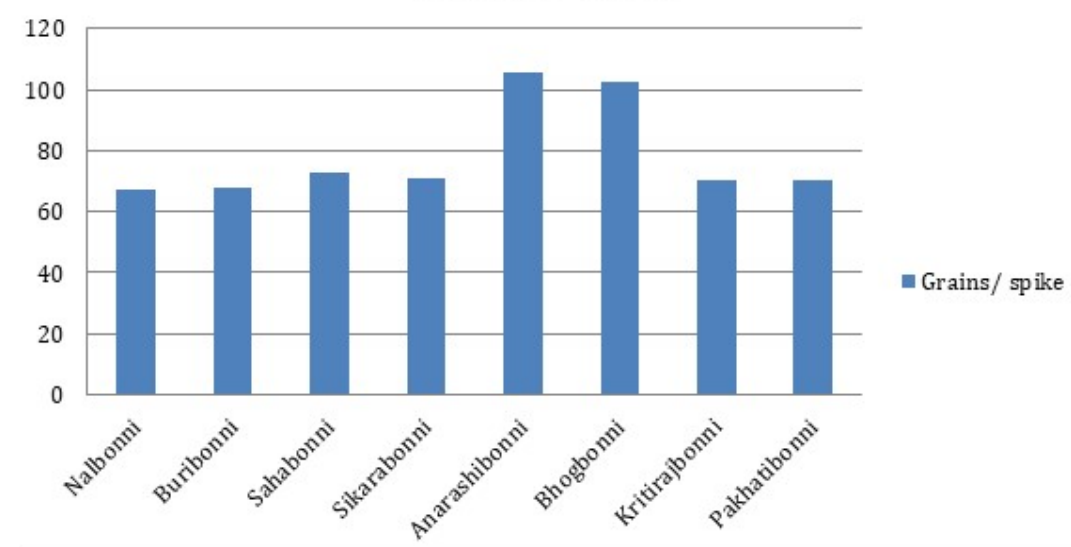

Figure 3. Number of grains per spike in different cultivars of Bora-rice of Bongaigaon district

\section{Paddy grain}

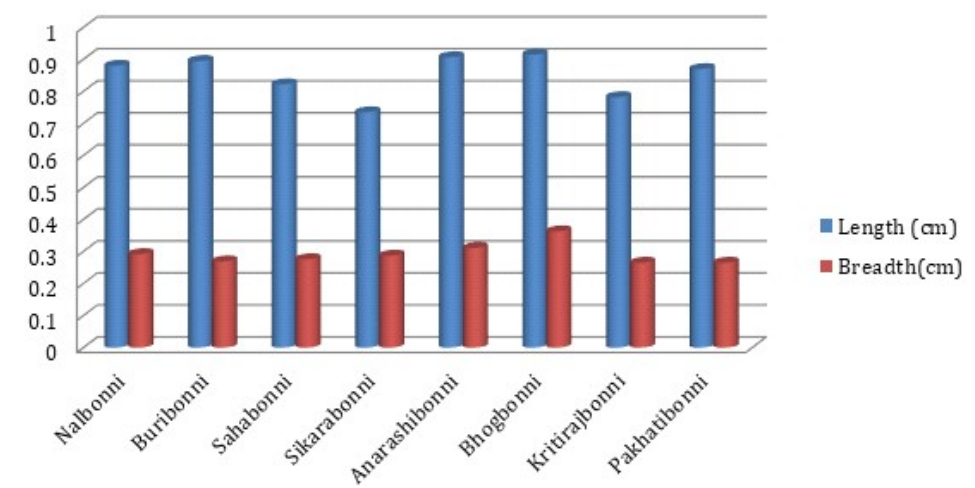

Figure 4. Length and breadth of paddy grains in different cultivars of Bora-rice of Bongaigaon district 
34 Characterization of Bora-rice cultivars in Bongaigaon district

Table 3. Weight, volume and colour of grains in different cultivars of Bora-rice cultivated in Bongaigaon district during the period of 2014 to 2016

\begin{tabular}{|l|l|l|l|l|l|l|}
\hline \multirow{2}{*}{ Cultivar } & \multicolumn{2}{|c|}{$\begin{array}{c}\text { 1000 grains } \\
\text { weight }\end{array}$} & \multicolumn{2}{c|}{$\begin{array}{c}1000 \text { grains } \\
\text { volume }\end{array}$} & \multicolumn{2}{c|}{ Grain colour } \\
\cline { 2 - 7 } & Paddy & Rice & Paddy & Rice & \multicolumn{1}{|c|}{ Paddy } & \multicolumn{1}{c|}{ Rice } \\
\hline Nalbonni & 24.50 & 20.00 & 15.0 & 11.0 & Teak brown & Mushroom \\
\hline Buribonni & 19.60 & 18.90 & 20.0 & 15.0 & Pale cream & Summer sprinkle \\
\hline Sahabonni & 22.00 & 16.52 & 15.0 & 12.5 & Leaf brown & Corel shell \\
\hline Sikarabonni & 24.50 & 19.80 & 22.0 & 16.0 & Leaf brown & Sandal wood \\
\hline Anarashibonni & 22.70 & 19.60 & 19.0 & 12.2 & Midbuff & Mushroom \\
\hline Bhogbonni & 23.30 & 18.50 & 15.5 & 10.8 & Teak brown & Sandal wood \\
\hline Kritirajbonni & 21.24 & 19.49 & 13.90 & 10.0 & Teak brown & Mushroom \\
\hline Pakhatibonni & 22.00 & 16.50 & 20.4 & 11.8 & Brown & Mushroom \\
\hline
\end{tabular}

\section{Rice grains}

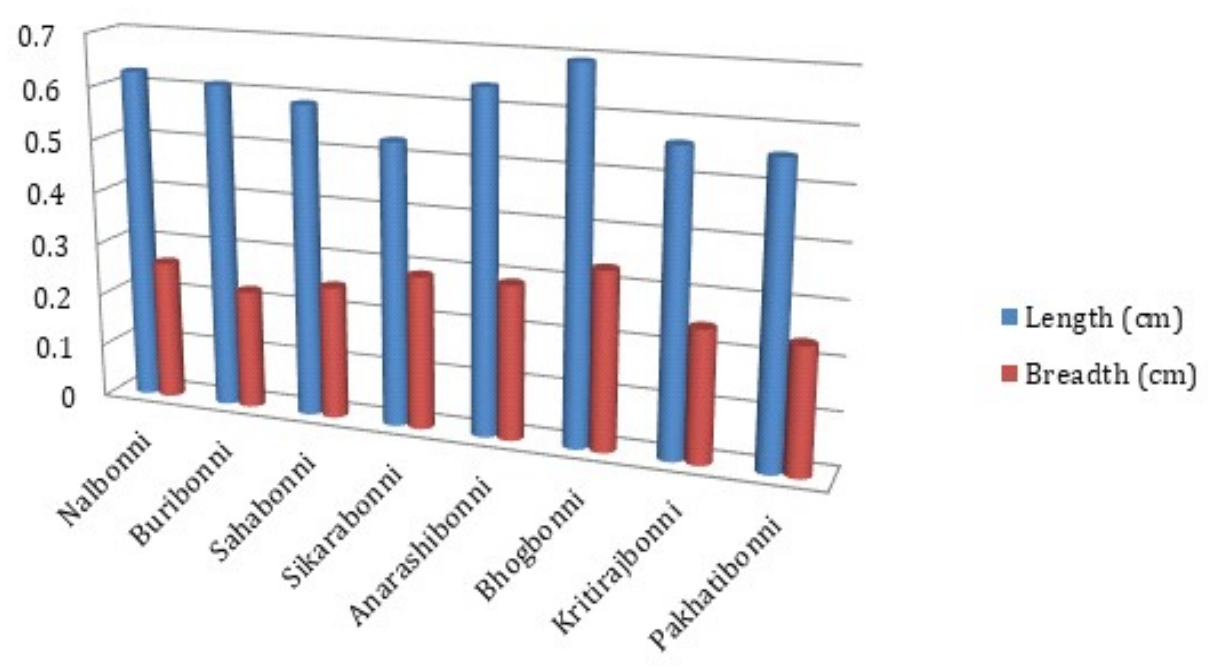

Figure-5. Length and breadth of rice grains in different cultivars of Bora-rice of Bongaigaon district

weight of 1000 grains of rice was found in Nalbonni $(20.00 \mathrm{~g})$ which was followed by Sikarabonni, Anarashibonni, Kritirajbonni, Buribonni and Pakhatibonni (16.50 g). Highest volume of 1000 grains of paddy was found in Sikarabonni $(22.00 \mathrm{cc})$ and was followed by Pakhatibonni, Buribonni, Anarashibonni, Bhogbonni, Sababonni, Nalbonni and Kritirajbonni (13.90 cc). Highest volume of 1000 grains of rice were observed in Sikarabonni $(16.0 \mathrm{cc})$ that was followed by Buribonni, Sahabonni, Anarashibonni, Pakbatibonni, Nalbonni, Bhogbonni and Kritirajbonni $(10.0 \mathrm{cc})$.

Regarding the colour of paddy in most of the indigenous cultivars of Bora-rice was generally found to be brown which may be teak-brown or leaf-brown in different cultivars. On the other hand, rice-grains in most of the cultivers Bora-rice were found to be mushroom and sandal-wood coloured. The rice-grains colour of Buribonni and Sababonni are summer sprinkle and coral shell. 
Table-2 shows the length and breadth of grain in different indigenous cultivars of Bora-rice cultivated in the study area. Length of the paddy grain varies from $0.735 \pm 0.039 \mathrm{~cm}$ to $0.915 \pm 0.038 \mathrm{~cm}$ while the breadth varies from $0.265 \pm 0.031 \mathrm{~cm}$ to $0.363 \pm 0.025 \mathrm{~cm}$ (Figure 4). The highest length of paddy-grain was observed in Bhogbonni. Length of the rice grain varies from $0.531 \pm 0.016 \mathrm{~cm}$ to $0.693 \pm 0.035 \mathrm{~cm}$ while the breadth varies from $0.224 \pm 0.014$ $\mathrm{cm}$ to $0.334 \pm 0.014 \mathrm{~cm}$ (Figure 5). In case of rice grain the highest length and breadth was observed in Bhogbonni.

\section{CONCLUSION}

Eight different cultivars of Bora-rice are being cultivated in the Bongaigaon district of Assam. Although basically all are glutinous, but the varieties studied showed morphological characteristics that are distinct from each other and can be helpful in their easy identification. Though the ethnic people treat these cultivars as their inherent properties but due to their sticky nature normal cooked rice has less demand to the common people. It is used only in preparing jalpan (snacks) and pitha (traditional rice-cake). Some special dishes are prepared from Bora rice in some ceremonies only. Due to its less popularity among common people farmers might discontinue the practice of cultivating these rice cultivars and can opt for other highly demandable ones. But each of the cultivar has its own importance. If one genotype is lost it is lost forever. Therefore there is an urgent need for characterization for proper recognition and sufficient incentive to encourage the farmers to grow these varieties that could help in the in situ on-farm conservation of these important indigenous paddy genotypes of Bongaigaon district.

\section{Acknowledgements}

Thanks to UGC (NERO) for providing financial support under Minor Research Project. The author is also thankful to Institutional Biotech Hub and Botany department of Birjhora Mahavidyalaya for extending the basic infrastructure for completion of the research activity. The author is also thankful to all the farmers of the study area and the students of Botany department, Birjhora Mahavidyalaya for their support and continuous help during field study and for sharing their knowledge on indigenous rice varieties.

\section{LITERATURE CITED}

BGR, IOCL 2010. Official records of Bongaigaon Refinary and Indian Oil Corporation Limited, Bongaigaon.

Pathak, P.K. 2001. Major cereal crops of Assam. In: Thakur, A.C.; Bhattacharya, H'; Sarma, D.K. (eds.), Agriculture in Assam: Directorate of extension education, Assam Agricultural University, Jorhat, India. Pp. 53 - 77.

Choudhury, B.; Khan, M.L. \& Dayanandan, S. 2013. Genetic structure and diversity of indigenous rice (Oryza sativa) varieties in the Eastern Himalayan region of Northeast India, Springer Plus December 2013, 2: 228

Deka, D.; Sarmah, B. \& Sharma, S. 2014. Conservation and Utilisation of indigenous Rice Varieties for a Sustainable Livelihood Security, Intn. J. Env. Res. Dev. 4(4): 293 - 294. ISSN 2249-3131

Hore, D.K. 2005; Rice diversity collection, conservation and management in Northeastern India, Genet. Resour. Crop Evol. 52: 1129 - 1140. 
36 Characterization of Bora-rice cultivars in Bongaigaon district

Roy, R. 2018. Diversity and phenotypic characters of Joha-rice (Oryza sativa L.) varieties cultivated in Bongaigaon district of Assam, India. Pleione 18(2): 249 - 254.

Sarma, R.N. \& Bahar, B. 2005. Genetic variation of bora rice (glutinous rice) of Assam as revealed by RAPDs. Plant Genetic Resources Newsletter 144: 34 [Publisher IPGRI and $\mathrm{FAO}]$

Sharma, S.D.; Vellanski, V.R.; Hanki, K.L. \& Sing, R.P. 1971. Primitive and current cultivars of rice in Assam: A source of valuable genes. Curr. Sci. 40: 126 - 128.

SPSS Advanced Statistics 6.0., 1994, SPSS Inc.444 North Michigan Avencre, Chicago, Illinois. 60611

https//en.m.wikipedia.org 